\title{
Review of Literature on Social Media Use: A Bibliometric Analysis
}

\author{
Seydou Harouna Fatouma*, Shen Lei \\ Glorious Sun School of Business and Management, Donghua University, Shanghai, China
}

\section{Email address:}

sfatouka@gmail.com (S. H. Fatouma),slei@dhu.edu.cn (Shen Lei)

${ }^{*}$ Corresponding author

\section{To cite this article:}

Seydou Harouna Fatouma, Shen Lei. Review of Literature on Social Media Use: A Bibliometric Analysis. European Business \& Management. Vol. 4, No. 4, 2018, pp. 101-111. doi: 10.11648/j.ebm.20180404.11

Received: July 14, 2018; Accepted: August 19, 2018; Published: October 19, 2018

\begin{abstract}
As social media has been a hot topic for researchers over the past few years, conducting some type of literature review seemed to be essential to inform the research [1]. The objective of this research is to review and assess current social media use trends by using Histcite software for bibliometric analysis and information visualization. The paper provides a detail review of related literature regarding the concept of social media use by several organizations, its definition and research gaps found in the review are also discussed. Besides the study shows the highly cited journals and authors related to social media use from 2008 to 2018. The bibliometric analysis reveals that 1232 articles using the term "social media use" have been published during the selected years. From the review conducted, it can be identified that social media use literature was covered by more than 350 journals among which "computers in human behavior" journal stands first with 65 articles. Likewise, the paper explores the highly cited authors and cited papers from social media use literature which indicates that highest numbers of papers have been written by co-authors. The h-index (that provides an index based on a list of publications ranked in descending order by the Times Cited count) of social media use literature is 45 . In conclusion, this review found that researches focusing on employees social media use is very limited and rather in its infancy. Only few studies have addressed social media usage by employees.
\end{abstract}

Keywords: Social Media Use, Bibliometric Analysis, Literature Review, Research Gaps

\section{Introduction}

As the study of social media has been a hot topic for researchers over the past few years, conducting some type of literature review seemed to be essential to inform the research [1]. Alongside of recent trends in web technologies, making profitable use of social media is at the top of the agenda for many organizations, social media refers to online services that support social interactions among users through highly accessible and scalable web-based publishing techniques [2]. In the public and private sector, social media initiatives are booming, with increasing agreement among users on the importance of using social media platforms to interact with others. Given that, this paper gives an overview of past research on social media use and the factors relevant to this dissertation. Following [3], this literature review was carried out in two main steps: 1) selecting the relevant sources to be searched, and 2) defining the search strategy in terms of time frame, search terms, and search fields. This paper provides a detail review of related literature regarding the concept of social media use in several organizations, its definition and research gaps found in the review are discussed. Besides the study shows the highly cited journals and authors related to social media use from 2008 to 2018 . Prior to the review, Histcite software was used for bibliometric analysis and information visualization. Bibliometric is the branch of information theory that attempts to analyze quantitatively and statistically the properties and behavior of recorded knowledge. Through this technique, only the recorded knowledge can be study, not the knowledge itself. Documents used in this study were based on the online database Web of Science. The period of study 
covered is from 2008 to $25^{\text {th }}$ June 2018 (10 years). The keyword "social media use" has been used as the search term in the field of title and the time period is limited to 2008 to 2018. Once a marked list of papers has been created, the resulting export file is processed by HistCite ${ }^{\mathrm{TM}}$ (Bibliometric Analysis and Visualization Software developed by Garfield and colleagues) to create tables ordered by author, year as well as citation frequency.

\section{Method and Bibliometric Analysis}

The focus of this analysis is the title search "social media use", using the tool Web of Science ${ }^{\circledR}$, a service to access the world's leading scholarly literature in different disciplines by examining various sources. Bibliometric analysis is the quantitative description of literature that helps in measuring the patterns of all forms of recorded information and their producers. Bibliometry is a quantitative analysis of the bibliographic characteristics of a growing body of literature. This analysis is represented by indices such as author and country productivity, as well as the amount of production over time. Bibliometric studies have been increasingly conducted to map academic articles and technological products of different scientific fields, determine collaboration standards between authors, institutions, research groups, and other analysis parameters, define the main areas of research and present the impacts of scientific article publications [4]. The main objective of the bibliometric analysis is to explore the following characteristics of social media literature from 2008 to $25^{\text {th }}$ June 2018 .

1. To find out year wise growth of publications

2. To find the document wise research publications in social media use research

3. To find the authorship productivity

4. To find out important journal publication of research out put

5. To examine the distribution of top ten countries during the study period

6. To identify the most productive institutions in social media research

7. To find top ten highly cited articles in social media research.

Documents used in this study were based on the online database Web of Science. The period of study covered is from 2008 to $25^{\text {th }}$ June 2018 (10 years). The keyword "social media use" has been used as the search term in the field of title and the time period is limited to 2008 to 2018. A total of 1232 records were retrieved from all databases of Web of science. The search as show in table 1 included 902 records from Web of Science Core Collection, 158 records from Inspec and the remaining 172 records are from SciElo Citation Index, KCI-Korean Journal Database, Chinese Science Citation Database and from Medline (Table 1). Once a marked list of papers has been created, the resulting export file is processed by HistCite ${ }^{\mathrm{TM}}$ (Bibliometric Analysis and Visualization Software developed by Garfield and colleagues) to create tables ordered by author, year or citation frequency as well as historiographs.
Table 1. Records from Web of Science Databases.

\begin{tabular}{ll}
\hline Databases & Records \\
\hline Web of Science Core Collection & 902 \\
SciElo Citation Index & 3 \\
KCI-Korean Journal Database & 70 \\
Chinese Science Citation Database & 1 \\
Medline & 98 \\
Inspec & 158 \\
Total records & 1232 \\
\hline
\end{tabular}

The analysis of the data has been done with a view to measure the growth of social media use literature over the years, author's productivity, institution, country wise distribution of papers and highly cited papers. A general picture of social media use literature retrieved from Web of Science ${ }^{\circledR}$ is given in Table 2 . It reflects citations to source items indexed within Web of Science ${ }^{\circledR}$. A Cited Reference Search was performed to include citations of items not indexed within Web of Science $\AA$. This was cited 9874 times, 8803 times without self-citations. Average citations per item were 8.01. The $h$-index (Hirsch index that provides an index based on a list of publications ranked in descending order by the times cited count) was 45 .

Table 2. General Observations on Social Media Literature during 20082018 .

\begin{tabular}{ll}
\hline Results found & $\mathbf{1 2 3 2}$ \\
\hline Sum of the Times Cited & 9874 \\
Sum of Times Cited without self-citations & 8803 \\
Citing Articles & 7098 \\
Citing Articles without self-citations & 6636 \\
Average Citations per Item & 8.01 \\
h-index & 45 \\
\hline
\end{tabular}

During the period 2008-2018 scientists all over the world have produced a total of 1232 publications on social media use literature. Table 3 shows the year wise distribution of papers published on Web of Science database. There were only 2 records in 2009 and then it increased gradually and reached 309 in 2017. It is interesting to see that the last five years (2014-2018) more than 1000 articles were published by world scientists. The average number of publications per year was 1097.11 . The social media use literature grew gradually by publication years.

Table 3. Year Wise Growth of Social Media Use Literature.

\begin{tabular}{llll}
\hline No. & Publication Year & Records & \% \\
\hline 1 & 2009 & 2 & 0.162 \\
2 & 2010 & 12 & 0.974 \\
3 & 2011 & 28 & 2.273 \\
4 & 2012 & 64 & 5.195 \\
5 & 2013 & 130 & 10.552 \\
6 & 2014 & 145 & 11.769 \\
7 & 2015 & 215 & 17.451 \\
8 & 2016 & 297 & 24.107 \\
9 & 2017 & 309 & 25.081 \\
10 & 2018 & 60 & 4.870 \\
& Total & 1232 & 100 \\
\hline
\end{tabular}

From HistCite software, 499 most valuables papers were published by 1530 authors by using 323 journals. Table 4 
illustrates authors' records as Shensa Ariel got 10 records with a Global Citation Score of 26. The second, third and fourth places are occupied by Dr. Primack Brian A, Dr.
Sidani Jaime E and Dr. Chen Hsuan-Ting among the top 10 authors contributing in the field of social media use literature.

Table 4. Prolific Authors with Number of Records (First 10 Authors).

\begin{tabular}{|c|c|c|c|c|c|c|}
\hline No. & Authors & Recs & $\%$ & LCS & TGCS & $\mathbf{C R}$ \\
\hline 1 & Shensha Ariel & 10 & 2.0 & 29 & 77 & 483 \\
\hline 2 & Primack Brian A & 9 & 1.8 & 29 & 77 & 483 \\
\hline 3 & Sidani Jaime E & 8 & 1.6 & 29 & 77 & 483 \\
\hline 4 & Chen Hsuan-Ting & 6 & 1.2 & 4 & 8 & 331 \\
\hline 5 & Groshek Jacob & 6 & 1.2 & 2 & 10 & 149 \\
\hline 6 & Unknown & 5 & 1.0 & & 0 & \\
\hline 7 & Chan Michael & 5 & 1.0 & 3 & 6 & 275 \\
\hline 9 & Kim Yonghwan & 5 & 1.0 & 2 & 5 & 300 \\
\hline 10 & Lee Francis L. F. & 5 & 1.0 & 4 & 7 & 270 \\
\hline
\end{tabular}

Recs - Records; TGCS - Total Global Citation Score - LCS Local Citation Score - CR Cited References

The literature of social media use (2008-2018) retrieved from Web of Science ${ }^{\circledR}$ is spread over 300 journals. The journal 'Computers In Human Behavior' is in the top most position with 65 records (TGCS 104, TGCS/\% 15.1\%) followed by 'Journal Of Medical Internet Research' with 25 records. Table 5 shows the rank position of top ten journals.

Table 5. Journals with Number of Records (First 10 Source Titles).

\begin{tabular}{|c|c|c|c|c|c|c|c|}
\hline No. & Journals & Records & $\%$ & TLCS & TLCS\% & TGCS & TGCS\% \\
\hline 1 & Computers In Human Behavior & 65 & 5.276 & 39 & 12.5 & 4129 & 6.2 \\
\hline 2 & Journal Of Medical Internet Research & 25 & 2.029 & - & - & 2312 & 3.5 \\
\hline 3 & Government Information Quaterly & 17 & 1.380 & 16 & 5.1 & 1586 & 2.4 \\
\hline 4 & Information Communication Society & 17 & 1.380 & 6 & 1.9 & 1386 & 2.1 \\
\hline 5 & Cyberpsychology Behavior and Social Networking & 16 & 1.299 & 7 & 2.2 & 694 & 1.0 \\
\hline 6 & New Media Society & 15 & 1.218 & 9 & 2.9 & 1447 & 2.2 \\
\hline 7 & Proceedings of the Annual Hawaii International Conference on System Sciences & 13 & 1.055 & - & & - & \\
\hline 8 & Public Relations Review & 13 & 1.055 & 21 & 6.7 & 1202 & 1.8 \\
\hline 9 & Telematics and Informatics & 13 & 1.055 & & & - & \\
\hline 10 & Korean Journal of Journalism Communication Studies & 10 & 0.812 & & & - & \\
\hline
\end{tabular}

The productivity of social media use literature according to Web of Science is spread over variety of publication media like Articles, Meeting, Reviews, Abstract and others document types. It is evident from Table 6 that the distribution of research output according to publication type. It is an accepted fact that most of the scholarly communication of scientific research is published in Articles (83.279\%) and sometimes presented in Meetings, Abstracts, Editorials or other forms.

Table 6. Document Types Distribution of Social Media Use Literature.

\begin{tabular}{llll}
\hline SI. No. & Document Type & Records & \% \\
\hline 1 & Article & 1026 & 83.279 \\
2 & Meeting & 148 & 12.013 \\
3 & Others & 82 & 6.656 \\
4 & Review & 69 & 5.601 \\
5 & Abstract & 65 & 5.276 \\
6 & Editorial & 22 & 1.786 \\
7 & Letter & 6 & 0.487 \\
8 & Clinical trial & 3 & 0.244 \\
9 & Correction & 3 & 0.244 \\
10 & News & 3 & 0.244 \\
& Total & 1232 & 100 \\
\hline
\end{tabular}

Therefore, we map the scientific literature related to social media use in business and management field, the main authors, published articles involved in academic research on the subject could be identified. The records of academics publications, linked to the research area of "Business and Management categories", were obtained at the Web of Science Core Collection, from Thomson Reuters. The following search strategies were applied:
Tag topic $=$ "social media use"

Timespan $=2008$ to 2018

Indexes = SCI-EXPANDED, SSCI, CPCI-S, CCREXPANDED, IC

Document types: Articles (open access articles)

Records were imported from Web of Science Core Collection (raw data files in plain text format) to histcite software for a bibliometric analyses. Given the purpose of 
this study, regarding the use of social media in business and management purpose, only records linked to the Research Area of Business/Management Research -a subject categorization scheme (subject) of WoS- were selected, reducing the number of articles from 1232 to 974 . Then we excluded Meeting abstract, Proceedings paper, book review, letter, news items to select only articles which reduce the number to 34 open access articles.

The following are some advantages of using histcite software: (a) removal of duplicates; and (b) standardization ("cleaning") of the fields Authors, Author Affiliations (Organization and City and Country). Therefore from the 34 records of academics publications obtained, authors conduct a detailed literature review to link the research categories to key variables (see table 7). For example, As social media moves from "buzz word" status to strategic tool, [5] in her research made an online survey asking 283 professionals in some international corporations, nonprofits and boutiques about their use and perceived ubiquity within the industry related to social media, she found out that in general, practitioners have adopted nearly six different social media tools professionally out of 18 social media tools. Practitioners have clearly adopted the more established and institutional tools (e-mail, Intranet), yet they also seem very comfortable with blogs and podcasts and slower to integrate more technologically complicated tools. The most popular tool was used was email, followed by intranet, blogs, videoconferencing, podcast and video sharing. Lesser used tools were: instant message, events, social networking, text messaging, photo sharing and wikis. Another study conducts by Joanne Patroni [6] on 20 global retailers that has adopted social media to boost employees' productivity and innovation within their organizations. Similarly as shown in previous research, several organizations use enterprise social media to encourage their employees to collaborate, share knowledge, and innovate. Thus organizations motivate employees to use work-based social media and the cultural implications for innovative and routine work practices. The management of innovation is subject to a change from focusing on the individual's innovation contribution to innovation as a social and collaborative practice [7]. Under these circumstances, employees are considered to be valuable sources of internal opportunities for innovation [8, 7]. In fact, according to [9] employees constitute one of the most important sources for innovation. Moreover, managers should be to lead employees through the phases of identification by specifically targeting their identification levels and using the appropriate media. It is possible to relate this open employee ideation approach to the ideas behind the phenomenon of open innovation [10] where organizations open up their organizational boundaries and use both internal and external sources for innovation. [11] discussed the adoption of social media technologies such as blogs, wikis, social networking sites, social tagging, and micro blogging in organizational settings as managers hope that these new technologies will help improve important organizational processes. The study concluded that social media usage improved the transparency of the employee innovation process, and the diversity of employees commenting on the submitted ideas increased. However, to stay competitive, organizations need to focus on employees' creativity and innovative behavior and empower them psychologically. Researchers have identified many antecedents to followers' creativity and innovative behavior. Of these, human resource management appears to be one of the most influential constructs $[12,13]$. Discussing the role that sagacity plays between individual creative and innovative work, one reason for the positive and significant role of managers is that creativity often needs actions that are beyond normal work tasks; employees may feel fear and anxiety at the thought of generating new ideas. In such a situation managers can play a vital role in providing a risktolerant environment in which workers feel comfortable to generate and participate in novel useful ideas [14].

Table 7. Summary of Some Key Contributions on Social Media Use in Organizations.

\begin{tabular}{|c|c|c|c|c|c|c|}
\hline & Authors & Journal & Methodology & Purpose & Content & Results \\
\hline 1 & $\begin{array}{l}\text { Lindley } \\
\text { Curtis et } \\
\text { al (2009) }\end{array}$ & $\begin{array}{l}\text { Public } \\
\text { Relations } \\
\text { Review }\end{array}$ & online survey & $\begin{array}{l}\text { The purpose of this study } \\
\text { was to find out how } \\
\text { nonprofit public relations } \\
\text { practitioners are adopting } \\
\text { social media tools and if they } \\
\text { view them as credible }\end{array}$ & $\begin{array}{l}409 \text { nonprofit public } \\
\text { relations practitioners }\end{array}$ & $\begin{array}{l}\text { Findings indicate that women consider } \\
\text { Social media to be beneficial, whereas } \\
\text { men exhibit more confidence in actively } \\
\text { utilizing Social media. Organizations with } \\
\text { specified public relations departments } \\
\text { were more likely to adopt social media. }\end{array}$ \\
\hline 2 & $\begin{array}{l}\text { Ruthann } \\
\text { Weaver et } \\
\text { al. (2009) }\end{array}$ & $\begin{array}{l}\text { Public } \\
\text { Relations } \\
\text { Review }\end{array}$ & $\begin{array}{l}\text { Telephone } \\
\text { surveys }\end{array}$ & $\begin{array}{l}\text { Investigates the agenda- } \\
\text { building role of social media } \\
\text { content in journalists' work. }\end{array}$ & $(\mathrm{n}=200)$ United States & $\begin{array}{l}\text { Very little use of social media by these } \\
\text { business journalists }\end{array}$ \\
\hline 3 & $\begin{array}{l}\text { Bobby J. } \\
\text { Calder et } \\
\text { al. (2009) }\end{array}$ & $\begin{array}{l}\text { Journal of } \\
\text { Interactiv } \\
\text { e } \\
\text { Marketing }\end{array}$ & $\begin{array}{l}\text { Experiments } \\
\text { using } \\
\text { measurement } \\
\text { Scales } \\
\text { involving } 8 \\
\text { different } \\
\text { online } \\
\text { experiences. }\end{array}$ & $\begin{array}{l}\text { Consumer engagement with } \\
\text { a website. }\end{array}$ & 11 online media websites & $\begin{array}{l}\text { Personal and Social-Interactive } \\
\text { engagement. are positively associated } \\
\text { with advertising effectiveness }\end{array}$ \\
\hline 6 & $\begin{array}{l}\text { Angella J. } \\
\text { Kim et al. } \\
(2011)\end{array}$ & $\begin{array}{l}\text { Journal of } \\
\text { Business } \\
\text { Research }\end{array}$ & $\begin{array}{l}\text { Survey } \\
\text { questionnaire }\end{array}$ & $\begin{array}{l}\text { Five constructs of perceived } \\
\text { SSM activities of luxury } \\
\text { fashion brands are } \\
\text { entertainment, Interaction, }\end{array}$ & $\begin{array}{l}400 \\
\text { Survey questionnaires }\end{array}$ & $\begin{array}{l}\text { Enable luxury Brands to forecast the } \\
\text { future purchasing behavior of their } \\
\text { customers more accurately and provide a } \\
\text { guide, managing their assets and activities }\end{array}$ \\
\hline
\end{tabular}




\begin{tabular}{|c|c|c|c|c|c|c|}
\hline & Authors & Journal & Methodology & Purpose & Content & Results \\
\hline & & & & $\begin{array}{l}\text { trendiness, customization, } \\
\text { and word of mouth. Their } \\
\text { effects on value equity, } \\
\text { relationship } \\
\text { Equity, and brand equity are } \\
\text { significantly positive }\end{array}$ & & $\begin{array}{l}\text { perceived by consumers were significantly } \\
\text { efficacious to luxury fashion brands' } \\
\text { future profits marketing activities. SSM } \\
\text { activities perceived by customers are } \\
\text { influential to all Customer equity drivers }\end{array}$ \\
\hline 5 & $\begin{array}{l}\text { Richard } \\
\text { D. Waters } \\
(2009)\end{array}$ & $\begin{array}{l}\text { Public } \\
\text { Relations } \\
\text { Review }\end{array}$ & $\begin{array}{l}\text { Content } \\
\text { analysis }\end{array}$ & $\begin{array}{l}\text { Examines how these new } \\
\text { social networking sites are } \\
\text { being used by the } \\
\text { organizations to advance } \\
\text { their organization's mission } \\
\text { and programs. }\end{array}$ & $\begin{array}{l}275 \text { non profit } \\
\text { organization profiles on } \\
\text { Facebook }\end{array}$ & $\begin{array}{l}\text { This study found that nonprofits have not } \\
\text { incorporated the vast majority of the } \\
\text { Facebook applications available to them } \\
\text { into their social networking presence. } \\
\text { Several applications have been created by } \\
\text { Facebook and outside programmers that } \\
\text { are designed to help organizations with } \\
\text { their fundraising and relationship } \\
\text { cultivation efforts. }\end{array}$ \\
\hline 6 & $\begin{array}{l}\text { Kristen } \\
\text { Lovejoy } \\
(2012)\end{array}$ & $\begin{array}{l}\text { Public } \\
\text { Relations } \\
\text { Review }\end{array}$ & $\begin{array}{l}\text { Content } \\
\text { analysis }\end{array}$ & $\begin{array}{l}\text { Specifically it looks into the } \\
\text { organizations utilization of } \\
\text { tweet frequency, following } \\
\text { behavior, hyperlinks, } \\
\text { hashtags, public messages, } \\
\text { retweets, and multimedia } \\
\text { files. }\end{array}$ & $\begin{array}{l}73 \text { nonprofit } \\
\text { organizations }\end{array}$ & $\begin{array}{l}\text { The study found that the nation's largest } \\
\text { nonprofits are not using Twitter to } \\
\text { maximize stakeholder involvement. } \\
\text { Instead, they continue to use Social media } \\
\text { as a one-way communication channel as } \\
\text { less than } 20 \% \text { of their total tweets }\end{array}$ \\
\hline 7 & $\begin{array}{l}\text { Raj } \\
\text { Agnihotri } \\
(2017)\end{array}$ & $\begin{array}{l}\text { Journal of } \\
\text { Business } \\
\text { Research }\end{array}$ & $\begin{array}{l}\text { Empirical } \\
\text { study }\end{array}$ & $\begin{array}{l}\text { direct effects of sales-based } \\
\text { CRM customer relationship } \\
\text { management technology on } \\
\text { the behaviors of diligence, } \\
\text { information communication, } \\
\text { inducements, empathy and } \\
\text { sportsmanship. }\end{array}$ & 219 salespeoples in India & $\begin{array}{l}\text { Results lend support for the notion that } \\
\text { complimentarily exists between CRM } \\
\text { technology and social media, and they } \\
\text { provide empirical evidence that social } \\
\text { CRM has meaningful implications for } \\
\text { sales organizations. }\end{array}$ \\
\hline 8 & $\begin{array}{l}\text { Andrew } \\
\text { N. Smith } \\
(2012)\end{array}$ & $\begin{array}{l}\text { Journal of } \\
\text { Interactiv } \\
\text { e } \\
\text { Marketing }\end{array}$ & $\begin{array}{l}\text { A content } \\
\text { Analysis that } \\
\text { would allow } \\
\text { for } \\
\text { comparisons. }\end{array}$ & $\begin{array}{l}\text { This study tests hypotheses } \\
\text { regarding differences in } \\
\text { brand-related user-generated } \\
\text { content (UGC) between } \\
\text { Twitter (a microblogging } \\
\text { site), Facebook (a social } \\
\text { network) and YouTube (a } \\
\text { content community). }\end{array}$ & $\begin{array}{l}600 \text { UGC posts for two } \\
\text { retail-apparel brands } \\
\text { (Lululemon and } \\
\text { American Apparel) }\end{array}$ & $\begin{array}{l}\text { Findings show that while brand-related } \\
\text { UGC tends to differ across sites for some } \\
\text { facets of content (particularly promotional } \\
\text { Self-presentation and brand centrality), it } \\
\text { does not do so for others. } \\
\text { In addition, some cross-site content } \\
\text { patterns (e.g., 'marketer directed } \\
\text { Communication') appear to differ } \\
\text { significantly for brands that are more, } \\
\text { versus less, proactively managed. }\end{array}$ \\
\hline 9 & $\begin{array}{l}\text { Chenyan } \\
\text { Xu (2012) }\end{array}$ & $\begin{array}{l}\text { Informati } \\
\text { on \& } \\
\text { Managem } \\
\text { ent }\end{array}$ & $\begin{array}{l}\text { Survey } \\
\text { instrument }\end{array}$ & $\begin{array}{l}\text { Why individuals adopt SNS } \\
\text { methods, how IT systems are } \\
\text { developed and how } \\
\text { individuals, groups, } \\
\text { organizations, and markets } \\
\text { interact with. }\end{array}$ & $\begin{array}{l}148 \text { Social networking } \\
\text { sites (SNS) users, } \\
\text { undergraduate and } \\
\text { graduate students at a } \\
\text { public state university in } \\
\text { southwestern U.S. }\end{array}$ & $\begin{array}{l}\text { Immediate access, coordination and } \\
\text { affection have strong positive impacts on } \\
\text { SNS usage, and leisure has only a } \\
\text { marginal positive effect. Like other web- } \\
\text { based applications, SNS create a sense of } \\
\text { connectivity among users. }\end{array}$ \\
\hline 10 & $\begin{array}{l}\text { Rowena } \\
\text { L. } \\
\text { Briones } \\
(2010)\end{array}$ & $\begin{array}{l}\text { Public } \\
\text { Relations } \\
\text { Review }\end{array}$ & $\begin{array}{l}\text { Qualitative } \\
\text { research } \\
\text { methods, } \\
\text { interviews }\end{array}$ & $\begin{array}{l}\text { How social media are } \\
\text { effectively utilized in public } \\
\text { relations }\end{array}$ & $\begin{array}{l}40 \text { individuals from the } \\
\text { American Red Cross }\end{array}$ & $\begin{array}{l}\text { The study's participants realize the } \\
\text { importance of social media and how these } \\
\text { tools can be harnessed to build } \\
\text { Stronger relationships with publics such } \\
\text { as volunteers, the media, and the } \\
\text { community. }\end{array}$ \\
\hline 11 & $\begin{array}{l}\text { E.-H. } \\
\text { Kim and } \\
\text { Y. N. } \\
\text { Youm } \\
(2017)\end{array}$ & $\begin{array}{l}\text { Strategic } \\
\text { Managem } \\
\text { ent } \\
\text { Journal }\end{array}$ & Interviews & $\begin{array}{l}\text { Examined in the literature } \\
\text { include which stakeholders } \\
\text { are important and whether } \\
\text { firm-stakeholder } \\
\text { relationships matter for firm } \\
\text { Performance. }\end{array}$ & $\begin{array}{l}32 \text { state Public Utility } \\
\text { Commissions }\end{array}$ & $\begin{array}{l}\text { Stakeholder Response in the social media } \\
\text { space plays a key Role in differentiating } \\
\text { the different levels of receptivity. } \\
\text { Favorable reactions to firm initiated } \\
\text { Messages significantly affect analyst stock } \\
\text { Recommendations depending on the } \\
\text { messages 'growth implications. }\end{array}$ \\
\hline 12 & $\begin{array}{l}\text { Ana } \\
\text { María } \\
\text { Munar } \\
(2014)\end{array}$ & $\begin{array}{l}\text { Tourism } \\
\text { Managem } \\
\text { ent }\end{array}$ & $\begin{array}{l}\text { Quantitative } \\
\text { approach } \\
\text { questionnaire } \\
\text { survey }\end{array}$ & $\begin{array}{l}\text { This paper contributes to the } \\
\text { understanding of tourists' } \\
\text { social media adoption in } \\
\text { technologically advanced } \\
\text { nations with high levels of } \\
\text { information and } \\
\text { communication } \\
\text { technologies' (ICT) adoption }\end{array}$ & $\begin{array}{l}\text { Mallorca in } \\
\text { Mediterranean } \\
\text { Spain in a European } \\
\text { context }\end{array}$ & $\begin{array}{l}\text { Among the types of media reports } \\
\text { included in the survey, the } \\
\text { Mallorca visitors mainly spoke about their } \\
\text { tours by means of email } \\
\text { And mobile phone text and photo/video } \\
\text { messages. Social network sites such as } \\
\text { Facebook were the most popular among } \\
\text { the Scandinavian holidaymakers }\end{array}$ \\
\hline
\end{tabular}




\begin{tabular}{|c|c|c|c|c|c|c|}
\hline & Authors & Journal & Methodology & Purpose & Content & Results \\
\hline & & & & $\begin{array}{l}\text { and use, in relation to a } \\
\text { holiday location. }\end{array}$ & & $\begin{array}{l}\text { Studied here. Such social media platforms } \\
\text { allowing control of audiences, enabling } \\
\text { communicative practices }\end{array}$ \\
\hline 13 & $\begin{array}{l}\text { Nina } \\
\text { Eyrich } \\
(2008)\end{array}$ & $\begin{array}{l}\text { Public } \\
\text { Relations } \\
\text { Review }\end{array}$ & Online survey & $\begin{array}{l}\text { Asking Professionals about } \\
\text { their use and perceived } \\
\text { ubiquity within the industry } \\
\text { related to social media }\end{array}$ & $\begin{array}{l}283 \text { practitioners in } \\
\text { metropolitan area with } \\
\text { international public } \\
\text { relations firms or } \\
\text { international } \\
\text { corporations, nonprofits } \\
\text { and boutique public } \\
\text { relations firms in } \\
\text { America }\end{array}$ & $\begin{array}{l}\text { Overall, practitioners have adopted nearly } \\
\text { six different social media tools } \\
\text { professionally. Practitioners have clearly } \\
\text { adopted the more established and } \\
\text { institutional tools (e-mail, Intranet), yet } \\
\text { they also seem very comfortable with } \\
\text { blogs and podcasts. They are slower to } \\
\text { integrate more technologically } \\
\text { complicated tools that Cater to a niche } \\
\text { audience (e.g., text messaging, social } \\
\text { networks, virtual worlds). }\end{array}$ \\
\hline 14 & $\begin{array}{l}\text { Rob Law, } \\
\text { Dimitrios } \\
\text { Buhalis, } \\
\text { CihanCob } \\
\text { anoglu, } \\
(2014)\end{array}$ & $\begin{array}{l}\text { Internatio } \\
\text { nal } \\
\text { Journal of } \\
\text { Contempo } \\
\text { rary } \\
\text { Hospitalit } \\
\text { y } \\
\text { Managem } \\
\text { ent }\end{array}$ & $\begin{array}{l}\text { Qualitative } \\
\text { analysis }\end{array}$ & $\begin{array}{l}\text { It sets out to provide a } \\
\text { comprehensive overview of } \\
\text { the applications of ICT in } \\
\text { tourism and hospitality from } \\
\text { the perspectives of both } \\
\text { consumer and supplier. }\end{array}$ & 107 journal papers & $\begin{array}{l}\text { Consumer-related studies generally focus } \\
\text { on Examining information searching and } \\
\text { post-purchase behavior. Managers in } \\
\text { hospitality and tourism have attempted to } \\
\text { apply technologies to improve customer } \\
\text { service, enhance operational efficiency } \\
\text { and, ultimately, increase revenue. }\end{array}$ \\
\hline 15 & $\begin{array}{l}\text { Manaf } \\
\text { Bashir } \\
(2017)\end{array}$ & $\begin{array}{l}\text { Public } \\
\text { Relations } \\
\text { Review }\end{array}$ & $\begin{array}{l}\text { Qualitative } \\
\text { study In- } \\
\text { depth } \\
\text { interviews }\end{array}$ & $\begin{array}{l}\text { Understand how Kuwaiti } \\
\text { organizations use social } \\
\text { media to achieve PR } \\
\text { objectives, the advantages } \\
\text { and barriers PR (Public } \\
\text { relations) } \\
\text { Practitioners face when } \\
\text { using them as well as the } \\
\text { extent whether or not social } \\
\text { media have Changed PR. }\end{array}$ & 19 practitioners, Kuwait & $\begin{array}{l}\text { Kuwaiti organizations were found to use } \\
\text { Twitter and Instagram the most for } \\
\text { Promotion and information dissemination, } \\
\text { but the use is generally occasional and } \\
\text { reactive. }\end{array}$ \\
\hline 16 & $\begin{array}{l}\text { Zheng } \\
\text { Xiang } \\
\text { (2009) }\end{array}$ & $\begin{array}{l}\text { Tourism } \\
\text { Managem } \\
\text { ent }\end{array}$ & $\begin{array}{l}\text { Descriptive } \\
\text { analysis }\end{array}$ & $\begin{array}{l}\text { This study focuses on the } \\
\text { role of social media in the } \\
\text { online tourism domain. } \\
\text { As represented by a search } \\
\text { engine within a travel } \\
\text { planning context }\end{array}$ & 1150 Websites & $\begin{array}{l}\text { Social media, indeed, Constitute a } \\
\text { substantial part of the online tourism } \\
\text { domain and, Thus, play an important role } \\
\text { within the context of trip planning using a } \\
\text { search engine. }\end{array}$ \\
\hline 17 & $\begin{array}{l}\text { Eileen } \\
\text { Fischer } \\
(2010)\end{array}$ & $\begin{array}{l}\text { Journal of } \\
\text { Business } \\
\text { Venturing }\end{array}$ & $\begin{array}{l}\text { Qualitative } \\
\text { Study- } \\
\text { Interviews }\end{array}$ & $\begin{array}{l}\text { How the use of social media } \\
\text { may } \\
\text { Affect the entrepreneurs } \\
\text { themselves, how the use of } \\
\text { one social medium, Twitter, } \\
\text { may trigger effectual } \\
\text { entrepreneurial thinking and } \\
\text { action. }\end{array}$ & 12 entrepreneurs & $\begin{array}{l}\text { Entrepreneurs who invest a moderate } \\
\text { amount of time in social interactions via } \\
\text { social media like Twitter may } \\
\text { Actually benefit from new insights about } \\
\text { the resources that are available and what } \\
\text { they might be used for. }\end{array}$ \\
\hline 18 & $\begin{array}{l}\text { Xia Wang } \\
(2012)\end{array}$ & $\begin{array}{l}\text { Journal of } \\
\text { Interactiv } \\
\mathrm{e} \\
\text { Marketing }\end{array}$ & Survey data & $\begin{array}{l}\text { This article investigates peer } \\
\text { communication through } \\
\text { social media websites; } \\
\text { individual-level tie strength } \\
\text { and group-level } \\
\text { identification with the peer } \\
\text { group as antecedents }\end{array}$ & 292 participants, China & $\begin{array}{l}\text { Online consumer socialization through } \\
\text { peer communication also affects } \\
\text { purchasing decisions in two ways: directly } \\
\text { (conformity with peers) and indirectly by } \\
\text { reinforcing product involvement. }\end{array}$ \\
\hline 19 & $\begin{array}{l}\text { Omar S. } \\
\text { Itani } \\
(2017)\end{array}$ & $\begin{array}{l}\text { Industrial } \\
\text { Marketing } \\
\text { Managem } \\
\text { ent }\end{array}$ & $\begin{array}{l}\text { Qualitative } \\
\text { study }\end{array}$ & $\begin{array}{l}\text { Examines the use of social } \\
\text { media by business-to- } \\
\text { business (B2B) salespeople } \\
\text { to assist in their job } \\
\text { functions, how much a } \\
\text { salesperson uses social } \\
\text { media to assist in day-to-day } \\
\text { job tasks. }\end{array}$ & India & $\begin{array}{l}\text { Salespeople are limited in their use of } \\
\text { social media because guidance from their } \\
\text { organization is limited regarding best } \\
\text { practices and expectations for using social } \\
\text { media. This calls for more research to } \\
\text { identify the factors, especially } \\
\text { organizational and managerial ones, } \\
\text { which may enhance the level of } \\
\text { Salespeople's social media use. }\end{array}$ \\
\hline 20 & $\begin{array}{l}\text { Nina } \\
\text { Michaelid } \\
\text { ou (2011) }\end{array}$ & $\begin{array}{l}\text { Industrial } \\
\text { Marketing } \\
\text { Managem } \\
\text { ent }\end{array}$ & Mail survey & $\begin{array}{l}\text { Focusing on B2B SMEs and } \\
\text { their social networking } \\
\text { practices, particularly, usage, } \\
\text { perceived barriers, and the } \\
\end{array}$ & 1000 UK B2B SMEs & $\begin{array}{l}\text { Over a quarter of B2B SMEs in the UK } \\
\text { are currently using SNS to achieve their } \\
\text { marketing objectives, through SNS, B2B } \\
\text { firms can capitalize on pre-existing }\end{array}$ \\
\hline
\end{tabular}




\begin{tabular}{|c|c|c|c|c|c|c|}
\hline & Authors & Journal & Methodology & Purpose & Content & Results \\
\hline & & & & $\begin{array}{l}\text { measurement of } \\
\text { effectiveness of SNS as a } \\
\text { marketing tool. }\end{array}$ & & $\begin{array}{l}\text { business Networks to achieve word of } \\
\text { mouth and to make their brands better } \\
\text { known. }\end{array}$ \\
\hline 21 & $\begin{array}{l}\text { Naheed } \\
\text { Bashir } \\
(2017)\end{array}$ & $\begin{array}{l}\text { Technolo } \\
\text { gical } \\
\text { Forecastin } \\
\text { g \& } \\
\text { Social } \\
\text { Change }\end{array}$ & $\begin{array}{l}\text { Qualitative } \\
\text { approach } \\
\text { semi- } \\
\text { structured } \\
\text { interviews }\end{array}$ & $\begin{array}{l}\text { Examines the use of social } \\
\text { media as a potential source } \\
\text { of information for } \\
\text { developing new products in } \\
\text { MNCs }\end{array}$ & $\begin{array}{l}5 \text { multinational } \\
\text { companies }\end{array}$ & $\begin{array}{l}\text { Social media tools like Google analytics, } \\
\text { Facebook and online discussion forums } \\
\text { are fundamentally used in MNCs to } \\
\text { improve the communication and } \\
\text { information flow from consumers. }\end{array}$ \\
\hline 22 & $\begin{array}{l}\text { Andreas } \\
\text { M. } \\
\text { Kaplan } \\
(2010)\end{array}$ & $\begin{array}{l}\text { Business } \\
\text { Horizons }\end{array}$ & $\begin{array}{l}\text { Conceptual } \\
\text { analysis }\end{array}$ & $\begin{array}{l}\text { What the term "Social } \\
\text { Media" exactly means and } \\
\text { how Social Media differ } \\
\text { from the seemingly- } \\
\text { interchangeable related } \\
\text { concepts of Web } 2.0 \text { and } \\
\text { User Generated Content. }\end{array}$ & $\mathrm{Na}$ & $\begin{array}{l}\text { Classification of Social Media by social } \\
\text { presence/media richness and self- } \\
\text { presentation/self-disclosure. Social Media } \\
\text { allow firms to engage in timely and direct } \\
\text { end-consumer contact at relatively low } \\
\text { cost and higher levels of efficiency than } \\
\text { can be achieved with more traditional } \\
\text { communication tools. }\end{array}$ \\
\hline 23 & $\begin{array}{l}\text { Joanne } \\
\text { Patroni et } \\
\text { al. (2016) }\end{array}$ & $\begin{array}{l}\text { IT } \\
\text { Professio } \\
\text { nal }\end{array}$ & Case study & $\begin{array}{l}\text { Examined a global retailer's } \\
\text { social media implementation } \\
\text { and its influence on } \\
\text { employee productivity and } \\
\text { innovation. }\end{array}$ & 20 global retailers & $\begin{array}{l}\text { Built on productivity improvements from } \\
\text { real-time collaboration across departments } \\
\text { and stores, and the sharing of best } \\
\text { practices among online communities. The } \\
\text { new cloud-based social media allowed all } \\
\text { employees to connect, collaborate, and } \\
\text { share insights across the organization and } \\
\text { its different locations. }\end{array}$ \\
\hline 24 & $\begin{array}{l}\text { Zongchao } \\
\text { Li (2015) }\end{array}$ & $\begin{array}{l}\text { Public } \\
\text { Relations } \\
\text { Review }\end{array}$ & Online survey & $\begin{array}{l}\text { The paper introduces the } \\
\text { psychological empowerment } \\
\text { framework from community } \\
\text { psychology to the social } \\
\text { media context and aims to } \\
\text { assess the connections } \\
\text { between active and passive } \\
\text { socialmedia use and } \\
\text { psychological empowerment }\end{array}$ & 371 responses & $\begin{array}{l}\text { Found that active use was positively } \\
\text { related to both intrapersonal and } \\
\text { interactional empowerment, while only a } \\
\text { weak association was found between } \\
\text { passive use and interactional } \\
\text { empowerment. }\end{array}$ \\
\hline 25 & $\begin{array}{l}\text { Hossam } \\
\text { Ali- } \\
\text { Hassan } \\
(2015)\end{array}$ & $\begin{array}{l}\text { Journal of } \\
\text { Strategic } \\
\text { Informati } \\
\text { on } \\
\text { Systems }\end{array}$ & Survey & $\begin{array}{l}\text { Study the effect of three } \\
\text { categories of social media } \\
\text { use - social, hedonic, and } \\
\text { cognitive - on job } \\
\text { performance, as mediated by } \\
\text { three dimensions of social } \\
\text { capital. }\end{array}$ & $\begin{array}{l}1700 \text { employees of a } \\
\text { large } \\
\text { multinational } \\
\text { Information Technology } \\
\text { company, } 307 \text { responses }\end{array}$ & $\begin{array}{l}\text { Social and cognitive uses of technology } \\
\text { were empirically shown to have a } \\
\text { positive, albeit indirect, effect on } \\
\text { employees' routine and innovative job } \\
\text { performance. Hedonic use have a negative } \\
\text { impact on routine performance but } \\
\text { contribute to social ties development } \\
\text { which is a positive influence on } \\
\text { innovative performance. }\end{array}$ \\
\hline
\end{tabular}

\subsection{Defining Social Media}

The definition of social media itself has created a lot of discussions among scholars as the term is often confused to Web 2.0 and social networking. It is important to start with a widely-cited definition to distinguish between the two throughout the research. Social media is unique from other forms of communications and collaboration [15]. In general, the term Web 2.0, first used in 2004, refers to the enhanced capability whereby content and applications are continuously modified by all users [16]. Meanwhile, social networking sites refer to web sites that allow the "friending" of people and staying connected with friends and family [17].

Social media can be defined as a group of Internet-based applications built on technological foundations ofWeb2.0 that enable the creation and exchange of User Generated Content [16]. In broader terms, social media consists of social networks (Facebook, online communities), micro- blogging services (e.g. Twitter), video sharing (e.g., YouTube), and blogs. Social media provides a platform for firms to interact with their customers [18]. Social media are online tools that allow users to share content, collaborate, and build networks and communities, with the possibility of reaching and involving large audiences $[19,20]$ give a more detailed definition for enterprise social media. Previous authors described them as web-based platforms allowing workers to (a) communicate messages with specific coworkers or broadcast messages to everyone in the organization; (b) explicitly indicate coworkers as communication partners; (c) post, edit, and sort text and files; and (d) view the messages, connections, text, and files communicated, posted, edited and sorted by anyone else in the organization at any time of their choice.

\subsection{History of Social Media}

The Internet has revolutioned how people interact with each other on a daily basis. Prior to the Internet, staying 
connected to friends and family was difficult and costly. In today's world, staying connected is easy and accessible. The way people communicate changed when the first email was sent in 1971 [21, 16]. In 1978, the Bulletin Board System (BBS) was invented in order to allow users to exchange messages, data, news, and software, thus the beginning of the Internet [16]. In 1979, two individuals created Usenet, a worl wide discussion system that allowed users to post public messages [16]. The 1980s witnessed the introduction of online service providers such as Compuserve, Prodigy and America Online (AOL) [22] (Curtis, 2011). By 1989, British engineer Tim Berners-Lee began to work at CERN on what was to become the World Wide Web [21, 22].

During the 1990s, the Mosaic web browser was launched, GeoCities, one of the web's first social networking sites, was founded and personal home pages began to emerge [16]. The year 1995 marked the era for corporate web pages and ecommerce [16]. No-surprise that the current trend toward social media can be traced back to the internet' roots, since social media has transformed the World Wide Web from web sites that provided static information to web sites that serve as an information exchange platform between users [16].

The social media era dates back to 1998 when Bruce and Susan Abelson founded Open Diary, an early social networking site that brought online diary writers together into one community [16]. The technical advances and the growing availability of high-speed Internet access over the past 30 years have enabled a form of virtual content sharing, leading to the creation of social networking sites such as MySpace in 2003 and Facebook in 2004 that are fundamentally different and more powerful than the Bulletin Board System (BBS) of the late 1970s [21, 22, 16]. Social networking sites were followed by the video sharing site, YouTube, in 2005 and the micro blogging site Twitter, in 2006 [21]. The latest addition to the group of social media are virtual worlds (i.e. Second Life) and virtual game worlds (i.e. World of War craft), which provide a simulated environment inhabited by three-dimensional avatars that may interact with each other. The aforementioned evolution of technology touches on various forms of applications that provide clarity about what falls within the term of social media.

Although historically we have been able to identify different milestones of technological advances, categorization of such technologies may not be as simple. When considering the general definition of social media there is a need to distinguish various types of social media. The table 8 below provides six different types of social media.

Table 8. Six Types of Social Media.

\begin{tabular}{|c|c|c|}
\hline Categories & Description & Example \\
\hline $\begin{array}{l}\text { Collaborative } \\
\text { Projects }\end{array}$ & enables the joint creation of content simultaneously by many end users [16] & Wikipedia, Delicious \\
\hline $\begin{array}{l}\text { Blogs also referred } \\
\text { to as weblogs }\end{array}$ & are an online publication of numerous issues presented in a reverse & Twitter, Open Diary \\
\hline $\begin{array}{l}\text { Content } \\
\text { Communities }\end{array}$ & $\begin{array}{l}\text { the sharing of media content between users including text, videos, photos, and PowerPoint } \\
\text { presentations [16] }\end{array}$ & $\begin{array}{l}\text { BookCrossing, Flickr, YouTube, } \\
\text { Limewire and Slideshare }\end{array}$ \\
\hline $\begin{array}{l}\text { Social Networking } \\
\text { Sites }\end{array}$ & $\begin{array}{l}\text { are web-based services that allow individuals to construct a digital identity bydeveloping a } \\
\text { profile, articulating a list of users with whom they share a connection, viewing their list of } \\
\text { connections andviewing connections made by others within the system [17] }\end{array}$ & Facebook, MySpace, LinkedIn \\
\hline $\begin{array}{l}\text { Virtual Game } \\
\text { Worlds }\end{array}$ & $\begin{array}{l}\text { Platforms that replicate a three dimensional environment in which users can appear in the form } \\
\text { of avatars that interact with each other [16] }\end{array}$ & World of Warcraft, EverQuest \\
\hline $\begin{array}{l}\text { Virtual Social } \\
\text { Worlds }\end{array}$ & $\begin{array}{l}\text { Allows inhabitants or avatars choose their behavior freely and live a virtual life that may } \\
\text { resemble their real life [16]. }\end{array}$ & Second Life \\
\hline
\end{tabular}

\subsection{Gaps in Social Media Literature}

The available body of research indicated the gaps in literature on employees' social media usage. The preliminary review of literature helped the researcher generate ideas and explore sources that will contribute to the research. In terms of theory, several theorists have made valuable contributions to research, paving the way for others to build on and come up with more input. Social media have some unique features that may challenge the ability of existing theories and frameworks to explain cognition, affect, and behavior. These may require new theories and frameworks that will help in understanding social media and employees' behavior [23]. According to several studies on the adoption and use of social media by PR practitioners, there are plenty of social media studies in academic literature; significant gaps remain in understanding how employees are using the technology
[24]. Despite the rapid growth of social networking there is lack of theories in the phenomenon of social media. The potential benefits of social networking are not well understood [25]. Practically, managers are trying to understand how theirs companies should permit social media use for organizational purposes [23]. This is partly due to the lack of empirical research on employees' use of the technologies and platforms that underlie social networking and social media, argue Martin and Bavel [25]. This is true when it comes to the adoption of the technology in companies in China. Past research demonstrates a high level of interest in studying the usage and influence of social media as a tool of communication in the workplace [16]. However, research that is mainly focused on employees social media use is very limited and is rather in its infancy. Only few studies have addressed social media usage by employees. The researcher has reviewed scores of research papers, reports, academic articles, books, websites 
etc. using the social media as key search words that turned in thousands of titles. There are many past research studies or papers on social media in general but still more research needs to be done in HRM purpose. This research develops a sequential mediation model by fully integrating the links; this research focuses on three empirical gaps. First, few studies examine a sequential mediation model as this paper consider employee's social capital and their psychological empowerment mediating the relationship between social media and innovation. Second, there is a lack of attention to innovation as a measure of job performance outcome as most articles use financial (return on assets - ROA), organizational (e.g., productivity) and employee related (e.g., commitment) performance measures. Yet, Western knowledge economies consider innovation to be a driving force of economic growth, and international competitive advantage. Moreover, innovation is a function of a firm' ability to create, manage and maintain knowledge. Third, social media usage is becoming an important strategy for companies' competitive advantage achievement. Further research will answer the question that managers seek as whether they should allow social media at work or not.

\section{Summary and Conclusion}

In this paper literature review regarding social media use has been analyzed with a clear bibliometric tool. Based on Histcite software, the bibliographic information (titles, authors, years, countries, etc.) described several published articles and various aspects of management field. Moreover, present paper highlights important contribution from several research scholars in social media use field and includes the distinct features with a succinct description of the literature review. Based on the review, there are gaps in research that if filled will help companies understanding and using social media to get the benefits associated with the usage. Companies, as established by many scholars such as [26] have some sort of phobia when it comes to the use of social media. Similarly several scholars have noted that it is essential to include social media in any business strategy [27]. The available body of research indicated the gaps in literature on social media use in several organizations. The preliminary review of literature helped the researcher generate ideas and explore sources that will contribute to the research. In terms of hypothesis, several theorists have made valuable contributions to research, paving the way for others to build on and come up with more input. Past research demonstrates a high level of interest in studying the usage, adoption and influence of social media as a tool of communication in the workplace [16]. However, research that is mainly focused on employees social media use is very limited and is rather in its infancy. Only few studies have addressed social media usage by employees. Consequently most of the research focused on social media use by customers and end-users. Thus, in future research, the issue will be analyzed through the eyes of researchers to enlighten social media use impact on employees' job performance in companies by using an empirical study.

\section{References}

[1] Robert K. Yin, 2011, Qualitative Research from Start to Finish, First Edition, Guilford Press, ISBN1606239783, 9781606239780 .

[2] Dutta, S, (2010), What's your personnal Social Media Strategy, Harvard Business Review 88 (11), 127-130.

[3] Bandara, Wasana, Miskon, Suraya, \& Fielt, Erwin (2011) A systematic, tool-supported method for conducting literature reviews in information systems. In Tuunainen, Virpi, Nandhakumar, Joe, Rossi, Matti, \& Soliman, Wael (Eds.) Proceedings of the19th European Conference on Information Systems (ECIS 2011), Helsinki, Finland.

[4] Jacqueline Scott (2010) Quantitative methods and gender inequalities, International Journal of Social Research Methodology, 13:3, 223-236, DOI: 10.1080/13645579.2010.482258.

[5] Eyrich et al. (2008), PR practitioners' use of social media tools and communication Technology, Public Relations Review $34-412-414$.

[6] Patroni, Joanne (2016), Social Media use for internal and external innovation: An exploratory study in the retail industry, Australasian Conference on Information Systems, DOI: $10.13140 /$ RG.2.2.15292.85121.

[7] Jennie Björk, Fausto Di Vincenzo, Mats Magnusson \& Daniele Mascia (2011), The Impact of Social Capital on Ideation, Industry and Innovation, 18:6, 631-647, http://dx.doi.org/10.1080/13662716.2011.591976.

[8] Zejnilovic, Leid and Oliveira, Pedro and Veloso, Francisco M., (2012), "Employees as User Innovators: An Empirical Investigation of an Idea Management System". http://dx.doi.org/10.2139/ssrn.2083422.

[9] Anne Linke, Ansgar Zerfass, (2011) "Internal communication and innovation culture: developing a change framework", Journal of Communication Management, Vol. 15 Issue: 4, pp. 332-348, https://doi.org/10.1108/13632541111183361.

[10] Henry Chesbrough (2006), "Open Innovation: The New Imperative for Creating and Profiting from Technology", Harvard Business Press ISBN1422102831, 9781422102831.

[11] Treem, Jeffrey W. and Leonardi, Paul M., (2012), "Social Media Use in Organizations: Exploring the Affordances of Visibility". Editability, Persistence, and Association Communication Yearbook, Vol. 36, pp. 143-189.

[12] Shung Jae Shin and Jing Zhou, (2003). "Transformational Leadership, Conservation, and Creativity: Evidence from Korea”. The Academy of Management Journal Vol. 46, No. 6 p. 703-714 DOI: $10.2307 / 30040662$.

[13] John Kissi, Andrew Dainty, Anita Liu, (2012) "Examining middle managers' influence on innovation in construction professional services firms: A tale of three innovations", Construction Innovation, Vol. 12 Issue: 1, pp. 11-28, https://doi.org/10.1108/14714171211197472. 
[14] Aneika L. Simmons, Victor E. Sower, (2012) "Leadership sagacity and its relationship with individual creative performance and innovation", European Journal of Innovation Management, Vol. 15 Issue: 3, pp. 298-309, https://doi.org/10.1108/14601061211243648.

[15] Yajiong Xue, John Bradley, Huigang Liang, (2011) "Team climate, empowering leadership, and knowledge sharing", Journal of Knowledge Management, Vol. 15 Issue: 2, pp. 299312, https://doi.org/10.1108/13673271111119709.

[16] Kaplan, A. M., \& Haenlein, M. (2010). 'Users of the world, unite! The challenges and Opportunities of Social Media, Business horizons, 53 (1), 59-68.

[17] Boyd, D., \& Ellison, N. (2008). Social Network Sites: Definition, History, and Scholarship. Journal of ComputerMediated Communication, 13, 210-230. http://dx.doi.org/10.1111/j.1083-6101.2007.00393.x.

[18] Musfiq Mannan Choudhury \& Paul Harrigan (2014): CRM to social CRM: the integration of new technologies into customer relationship management, Journal of Strategic Marketing, DOI: 10.1080/0965254X.2013.87606.

[19] El Ouirdi, Mariam, Asma El Ouirdi, Jesse Segers, and Erik Henderickx. 2014. "Social Media Conceptualization and Taxonomy: A Lasswellian Framework." Journal of Creative Communications 9 (2): 107-126.

[20] Paul M. Leonardi et al. (2013) Enterprise Social Media: Definition, History, and Prospects for the Study of Social Technologies in Organizations, Journal of ComputerMediated Communication 19, 1-19, https://doi.org/10.1111/jcc4.12029.

[21] Borges, B. (2012). 40 Year History of Social Media. Retrieved on February 21, 2012 from http://www.findandconvert.com/2012/02/40-year-history-ofsocial-media/.

[22] Curtis, A. (2011). The Brief History of Social Media. Retrieved on February 20, 2011 from http://www.uncp.edu/home/acurtis/NewMedia/SocialMedia/ SocialMediaHistory.html.

[23] McFarland, L. A., \& Ployhart, R. E. (2015), "Social media: A contextual framework to guide research and practice". Journal of Applied Psychology, 100 (6), 1653-1677. http://dx.doi.org/10.1037/a0039244.

[24] Robson, Prue (2013), "Time to bridge the gaps: issues with current social media research in public relations". Australian and New Zealand Communication Association.

[25] Martin, A. and Bavel, R. V., (2013). "Assessing the Benefits of Social Networks for Organizations". Publications Office of the European Union Spain.

[26] Sundararaman C. (2016), "Social Media - from Wells to Wheels - Oil + Gas Monitor". Available at: http://www.oilgasmonitor.com/social-media-wells-wheels.

[27] Divya, S., \& Regi, B. (2014). "An Empirical Study on Effectiveness of Social Media as a Marketing Tool", International Journal of current research and academic review. Volume 2, 3. pp. 163-168.

[28] Lindley Curtis et al (2009), Adoption of social media for public relations by nonprofit Organizations, Public Relations Review 36 - 90-92.
[29] Ruthann Weaver Lariscy et al. (2009), An examination of the role of online social media in journalists' source mix, Public Relations Review 35 -314-316.

[30] Bobby J. Calder et al. (2009), An Experimental Study of the Relationship between Online Engagement and Advertising Effectiveness, Journal of Interactive Marketing 23- 321-331.

[31] Angella J. Kim et al., (2011), Do social media marketing activities enhance customer equity? An empirical study of luxury fashion brand, Journal of Business Research $65-1480$ 1486.

[32] Richard D. Waters et al. (2009), Engaging stakeholders through social networking: How nonprofit organizations are using Facebook, Public Relations Review 35 -102-106.

[33] Kristen Lovejoy et al. (2012), Engaging stakeholders through Twitter: How nonprofit organizations are getting more out of 140 characters or less, Public Relations Review 38 - 313-318.

[34] Raj Agnihotri et al. (2017), Examining the role of sales-based CRM technology and social media use on post-sale service behaviors in India, Journal of Business Research 81- 144-154.

[35] Andrew N. Smith et al. (2012), How Does Brand-related User-generated Content Differ across YouTube, Facebook, and Twitter? Journal of Interactive Marketing 26 -102-113.

[36] Chenyan Xu et al. (2012), It is not for fun: An examination of social network site usage, Information \& Management 49 210-217.

[37] Rowena L. Briones et al. (2010), Keeping up with the digital age: How the American Red Cross uses social media to build relationships, Public Relations Review 37 - 37-43.

[38] Eun-Hee Kim et al. (2017), How Do Social Media Affect Analyst Stock Recommendations? Evidence from S\&P 500 Electric Power Companies' Twitter Accounts, Strategic Management Journal 38: 2599-2622 DOI: 10.1002/smj.2678.

[39] Ana María Munar et al. (2014), Motivations for sharing tourism experiences through social media, Tourism Management 43- 46e54.

[40] Rob Law, Dimitrios Buhalis, Cihan Cobanoglu, (2014) "Progress on information and communication technologies in hospitality and tourism", International Journal of Contemporary Hospitality Management, Vol. 26 Issue: 5, pp. 727-750, https://doi.org/10.1108/IJCHM-08-2013-0367.

[41] Manaf Bashir et al. (2017), Public relations in an online environment: Discourse description of social media in Kuwaiti organizations, Public Relations Review 43 -777-787.

[42] Zheng Xiang et al. (2010), Role of social media in online travel information search, Tourism Management 31 -179-188.

[43] Eileen Fischer et al. (2010), Social interaction via new social media: (How) can interactions on Twitter affect effectual thinking and behavior? Journal of Business Venturing 26 -1- 18.

[44] Xia Wang et al. (2012), Social Media Peer Communication and Impacts on Purchase Intentions: A Consumer Socialization Framework, Journal of Interactive Marketing 26, 198-208.

[45] Omar S. Itania et al. (2017), Social media use in B2b sales and its impact on competitive intelligence collection and adaptive selling: Examining the role of learning orientation as an enabler, Industrial Marketing Management 66, 64-79. 
[46] Nina Michaelidou et al. (2011), Usage, barriers and measurement of social media marketing: An exploratory investigation of small and medium B2B brands, Industrial Marketing Management 40, 1153-1159.

[47] Naheed Bashir et al. (2017), Use of Social Media Applications for Supporting New Product Development Processes in Multinational Corporations, Technological Forecasting \& Social Change 120, 176-183.

[48] Andreas M. Kaplan et al. (2010), Users of the world, unite! The challenges and opportunities of Social Media, Business Horizons 53, 59-68.
[49] Zongchao Li (2015), Psychological Empowerment on Social Media: Who are the Empowered Users? Public Relations Review, Volume 42, Issue 1, Pages 49-59, https://doi.org/10.1016/j.pubrev.2015.09.001.

[50] Hossam Ali-Hassan et al. (2015), Linking dimensions of social media use to job performance: The role of social capital, Journal of Strategic Information Systems, http://dx.doi.org/10.1016/j.jsis.2015.03.001. 